\title{
Uçucu Külün Temmoku Sır Özelliklerine Etkileri
}

\author{
Ensar TAÇYILDIZ*
}

Özet

Uçucu küller termik enerji santralleri içinde öğütülmüş kömürün yanmasıyla ortaya çıkan atık bir malzemedir. Atık malzemeler çevre sorununun yanı sıra birçok durumda depolanma zorunluluğundan dolayı ilave maliyet getirmektedir. Bu nedenle birçok atık içeriğine bakılmaksızın ortadan kaldırılmaya çalışılmaktadır. Ancak atık malzemelerin de bir değeri vardır ve atıklar katma değeri yüksek ürünlerin elde edilmesinde kullanılabilir. Uçucu kül de atık bir malzemedir. Uçucu Kül içeriğinde silika, alüminyum ve demir yer almaktadır. Uygun oranlarda kullanıldığında seramik bünyelerin ve sırların birçok özelliğini olumlu yönde etkileyen bu malzeme, aynı zamanda seramik endüstrisinde üretim maliyetini düşürdüğü için tercih edilmektedir. ülkemizde son birkaç yıldan bu yana deneysel düzeyde kullanılmaya başlanan uçucu kül tüm dünyada, özellikle gelişmiş ülkelerde yıllardır seramik bünyelerde bir hammadde olarak tercih edilmektedir. Seyitömer termik santral uçucu külü fiziksel özellikleri, kimyasal içeriği, renklendirici kapasitesi ve yüksek oranda camsı faz içermesi nedeniyle temmoku sırlarda alternatif bir hammadde olarak kullanılabilir. Bu çalışmada uçucu külün temmoku sır üretiminde değerlendirilmesi amaçlanmıştır. Uçucu kül, temmoku sır reçetelerine ilave edilmiş ve sır özelliklerine etkileri araştırılmıştır.

Anahtar Sözcüikler: Uçucu kül, temmoku, sır, renklendirici, atık malzeme.

\section{The Effects of Fly Ash on the Temmoku Glaze Properties}

\section{Abstract}

Fly ashes are waste products of coal combustion in thermal power plants. Waste materials cause environmental problems in addition to additional costs accrued due to their storage requirement. Therefore, most waste materials are tried to be disposed without taking into account their content. However waste materials are also valuable and they can be used in the production of high value-added products. Fly ash is a waste material too. Fly ash contains silica, aluminum and iron. When used in correct proportions, this material doesn't only enhance and improve many characteristics of ceramic bodies and glazes but also reduces the cost of ceramic production, which makes it a favorable choice in ceramic industry. Fly ash, which has been used experimentally in our country in the last couple of years, has been a raw material for ceramic bodies-glazes and preferred especially by developed countries worldwide. Owing to its physical characteristics, chemical composition, coloring capability and high level of glass content, Seyitömer thermal power plant's fly ash can be used as an alternative raw material in temmoku glazes. This study aims to benefit from fly ash in the production of temmoku glaze. Fly ash is added into glaze recipes and its effects on e glaze properties are examined.

Keywords: Fly ash, temmoku, glaze, colourant, waste material. 


\section{Giriş}

Gün geçtikçe daralan rezervler nedeniyle seramik endüstrisinde yüksek kaliteli hammaddelerin temini ve dolayısıyla kullanımı giderek zorlaşmaktadır veya kalitesiz malzemeler kullanılmaktadır. Kalitesiz hammadde kullanımı yerine üretim sonucunda elde edilen atık malzemelerin ya da diğer endüstri kollarından gelen ikincil olarak adlandırılan hammaddelerin yeniden kullanılabileceğine yönelik çalışmalar durmadan artmaktadır (Kaya ve Turan, 2004:48).

Uçucu küller termik enerji santrallerinde öğütülmüş kömürün yanmasıyla ortaya çıkan atık bir malzemedir. Genellikle endüstride kullanılmayan düşük kalorili kömürlerin çok ince ögütülerek termik santral fırınında yakılması sırasında yukarıya yükselen uçucu küller, bacanın üst kısmında elektrofiltreler veya siklon adı verilen toz tutucularda elektrostatik veya mekanik yöntemlerle tutulan malzemelerdir (Topçu ve Canbaz, 2001: 12).

Uçucu küllerin rengi içeriğinde yer alan karbon oranına bağlı olarak değişse de genellikle gridir (Maitra, 1999:32). Dünyadaki yıllık uçucu kül üretim miktarı yaklaşık 450 milyon ton civarında olup, bunun yaklaşık 15 milyon tonu Türkiye'de üretilmektedir. Dünya üretiminin çok az bir kısmı beton ve çimento üretiminde kullanılmaktadır (Karasu vd, 2004: 2501). Bunun yanı sıra, uçucu küller seramik endüstrisinde tuğla, karo üretiminde maliyeti düşürmek için ana hammadde olarak da kullanılmaktadır (Karasu vd. 2004: 2501; Mishulovich ve Evanko, 2003:1; Ilic vd, 2003:331). Yapılan çalışmalara göre uçucu külün karo üretiminde \% 30-40 oranında ana hammadde olarak kullanılabileceği belirtilmektedir (Shah and Maiti, 2001:145-147). Ancak yapılan bir başka araştırmada karo üretiminde reçetede kullanılan uçucu kül miktarı arttıkça, ürünün yaş mukavemetinin azaldığı belirlenmiştir (Zimmer and Bergaman, 2006:62).

Uçucu kül \% 60-90 camsı bileşen ihtiva etmekte olup, çok ince taneciklerden meydana gelmektedir. Uçucu küllerin tane şekli yuvarlaktır ve çapları 1-200 $\mu \mathrm{m}$ arasında değişmektedir. Taneciklerin yaklaşık \% 75'inin çapı $45 \mu$ m'den, \% 50'den çoğu $\mu$ m'den büyüktür (http://www.kutahyacimento. com/tr). Ayrıca uçucu kül kimyasal olarak önemli miktarda demir oksit içermektedir. Bu durum uçucu külün demir içerikli temmoku sırlarda alternatif bir hammadde ve renklendirici olarak kullanılabileceği olasılığını artırmaktadır.

Temmoku, orijini Çin olan ve Japonya'da demire doyurulmuş sırlar için kullanılan benekli, yüzeyi yanardönerli siyah-pas rengi sırlar için kullanılan bir terimdir (Peterson, 2004:238).

Temmoku sırlar yüzey özelliklerine ve yapıldığı yere göre leopar benekli, temmoku-zen, chien-yao, yuteki-temmoku, yohen temmoku, keklik tüyü benekli ve tavşan kürkü temmoku olarak isimlendirilmektedir.

Temmoku sırlar, seramikte temel hammaddeler olarak bilinen Kuvars, Feldspat, Kaolin, Dolomit, Mermer gibi hammaddelerin bileşiminden oluşan, yüksek oranda demir içeren ve yaklaşık 1280 oC ve üzerindeki sıcaklıklarda elde edilen sırlardır. Bu sırların elde edilmesinde önemli faktörler vardır. Bunlardan birincisi reçete bileşimi, ikincisi uygulama biçimi ve üçüncüsü pişirme programıdır. Temmoku sırları çeşitli yüzey özelliklerine sahip olup hem indirgen hem de oksidasyonlu firın atmosferinde elde edilmektedir.

Temmoku sırların pişirimi sırasında fırın sıcaklığı 1280 oC'ye yükseltildiğinde erimiş sır içerisinde birbirine karışmayan iki faz oluşur. Bunlardan birisi silikaca zengin sıvı ve diğeri demirce zengin fazlardır. Böyle yüksek bir sıcaklıkta sır oluşumunun temel nedeni, erimiş sır içerisinde Fe203'ün çözünmesi ve 02 kabarcıklarının meydana gelmesidir. Muhtemelen demirce zengin oldukça düşük viskoziteli sıvı faz, kabarcıklar etrafında toplanır. Bu durumda kabarcıklardan bir kısmı birbirine karışır ve daha büyük kabarcıklar oluşur. Bu büyük kabarcıklar yüksek viskoziteli silikaca zengin sıvının yüzeyine ulaşır ve kabarcıkların parçalanması sonucunda sır yüzeyinde benekli bir görünüm ortaya çıkar (Naoyuki,1982:66; Weidong vd. 2008:1474).

Bu çalışmada endüstriyel bir atık olan Seyitömer termik santral uçucu külü, uygulandığı yüzeye estetik bir değer ve teknik özellikler katan artistik sırlardan biridir. Temmoku sırlarda hem bir hammadde hem de renklendirici olarak kullanılabileceği düşünülmüş ve çalışmalar bu bağlamda sürdürülmüştür. Temmoku sır reçetelerinde kullanılan hammadde ve renklendirici yerini alacak şekilde belli oranlarda uçucu kül ilavesiyle temmoku sır üretimi yapılarak sır üretim maliyetinin düşürülmesi ve atık malzemenin ekonomiye kazandırılması amaçlanmıştır. 


\section{Malzeme ve Yöntem}

Uçucu külün temmoku sır özelliklerine etkilerinin araştırıldığı bu çalışmanın ilk aşamasında işletmeden 50 kg uçucu kül numunesi alınmıştır. 50 kg'lık uçucu kül yığından konileme dörtleme yöntemiyle numune hazırlanmış (Wills, 1981:51), uçucu külün ve reçetede kullanılacak diğer hammaddelerin kimyasal analizleri yapılmıştır. Bu hammaddelerin kimyasal analizi Tablo 1'de, uçucu külün doğal rengi Şekil 1'de ve 800 oC'de pişme rengi Şekil 2'de verilmiştir. Çalışmanın ikinci aşamasında temmoku sır oluşturmak amacıyla iki farklı grup sır reçetesi oluşturulmuş ve denemeler bu bağlamda sürdürülmüştür. Birinci grup sır reçetelerinde dolomit miktarı azaltılarak uçucu kül miktarı attırılmıştır. Ayrıca reçeteye artan oranlarda demir oksit ilave edilmiştir. Bu sırlar 'uçucu kül-demir oksitli' temmoku sırlar olarak adlandırılmıştır. İkinci grup sır reçetelerinde ise reçete-demir oksit miktarı sabit tutulmuş, uçucu kül artan oranlarda sır reçetelerine ilave edilmiştir. Bu sırlar 'uçucu kül ilaveli' temmoku sırlar olarak adlandırılmıştır.

Hazırlanan sır reçetelerinin her biri 100 gr kuru hammadde kapasiteli porselen hazneli jet değirmende 10 dakika süreyle öğütülmüştür. Ögütme işleminde su oranı hammadde miktarının \% 70’i olarak seçilmiştir. Hazırlanan sırlar 100 mesh'lik elekten geçirildikten sonra stonewaer bünyeden oluşan $60 \mathrm{~mm}$ çapında ve $7 \mathrm{~mm}$ kalınlığında bisküvi pişirimi yapılmış deney plakası üzerine akıtma yöntemiyle uygulanmıştır. Sırlar elektrikli kamara tipi fırında oksidasyonlu ortamda 1200 oC'de, şekil 1'de verilen pişirim eğrisi uygulanarak pişirilmiştir. Pişirme işlemi sonrası reçete bileşimlerine göre temmoku sır oluşturma ve yüzey özellikleri değerlendirilmiştir.

Tablo 1. Hammaddelerin Kimyasal Analiz Sonuçları

\begin{tabular}{lcccccc}
\hline$\%$ & Na.Feldspat & K.Feldspat & Uleksit & Dolomit & U.Kül & Kuvars \\
\hline $\mathrm{SiO}_{2}$ & 67.07 & 66.55 & - & 0.10 & 53.69 & 98.30 \\
$\mathrm{Al}_{2} \mathrm{O}_{3}$ & 19.69 & 17.42 & 0.84 & 1.26 & 20.79 & 0.36 \\
$\mathrm{Naa}_{4} \mathrm{O}$ & 11.18 & 3.17 & 8.40 & - & 0.53 & 0.69 \\
$\mathrm{~K}_{2} \mathrm{O}$ & 0.79 & 10.32 & 0.25 & - & 2.70 & - \\
$\mathrm{CaO}$ & 0.53 & 0.80 & 16.20 & 31.20 & 3.40 & 0.05 \\
$\mathrm{MgO}$ & 0.11 & 0.70 & - & 21.80 & 4.09 & 0.28 \\
$\mathrm{~B}_{2} \mathrm{O}_{3}$ & - & - & 45.51 & - & -- & - \\
$\mathrm{TiO}_{2}$ & 0.21 & - & - & - & - & - \\
$\mathrm{Fe}_{2} \mathrm{O}_{3}$ & 0.12 & 0.20 & - & - & 11.80 & 0.02 \\
$\mathrm{SO}_{3}$ &.-- &.- &.-- & - & 0.99 & - \\
$\mathrm{A.Z}$ & 0.30 & 0.84 & 28.80 & 46.64 & 2.01 & 0.30 \\
\hline
\end{tabular}
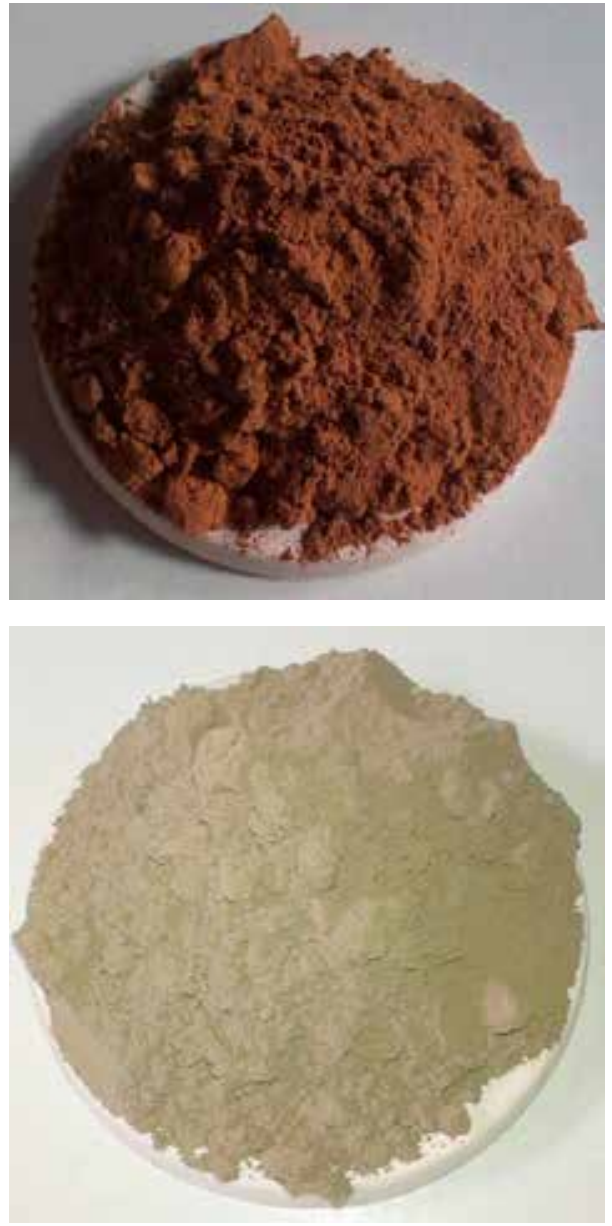

Resim 1. Uçucu Külün Doğal Rengi Resim 2. Uçucu Külün Pişme Rengi

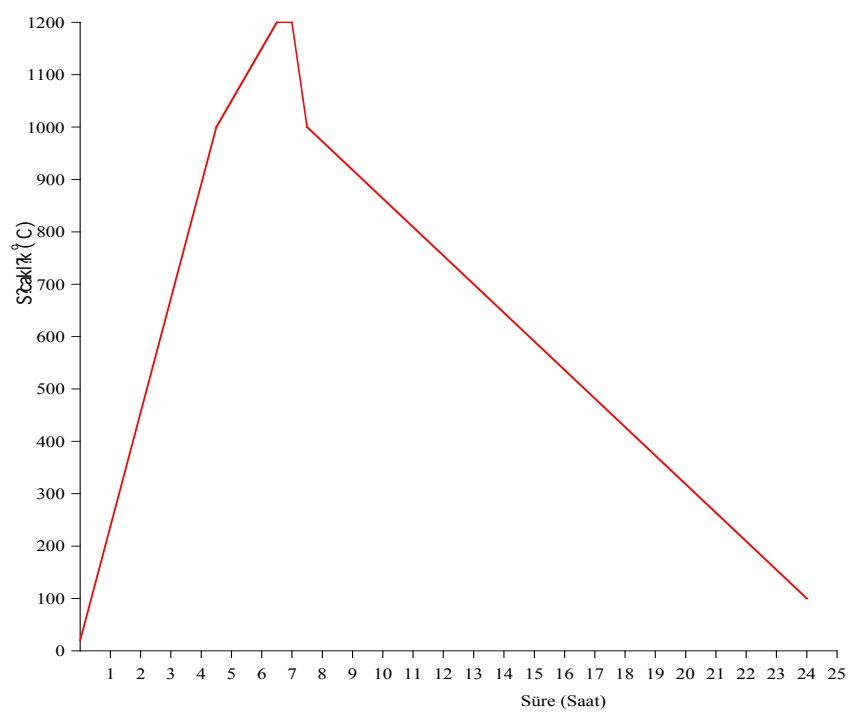

Şekil 1. Pişirme eğrisi 


\section{Bulgular ve Değerlendirme}

\subsection{Uçucu Kül - Demir Oksitli Temmoku Sırlar}

Uçucu külün temmoku sır özelliklerine etkilerini araştırmak amacıyla hazırlanan 'Uçucu Kül- Demir Oksitli’ temmoku sırların reçete bileşimi ve yüzey özellikleri Tablo 2'de, 1200 oC'de pişirme sonrası görsel sonuçları Resim 3'te ve 5 nolu sıra ait görsel detay Resim 4'de verilmişstir.

Tablo 2. Uçucu Kül- Demir Oksitli Temmoku Sırların Reçete ve Yüzey Özellikleri

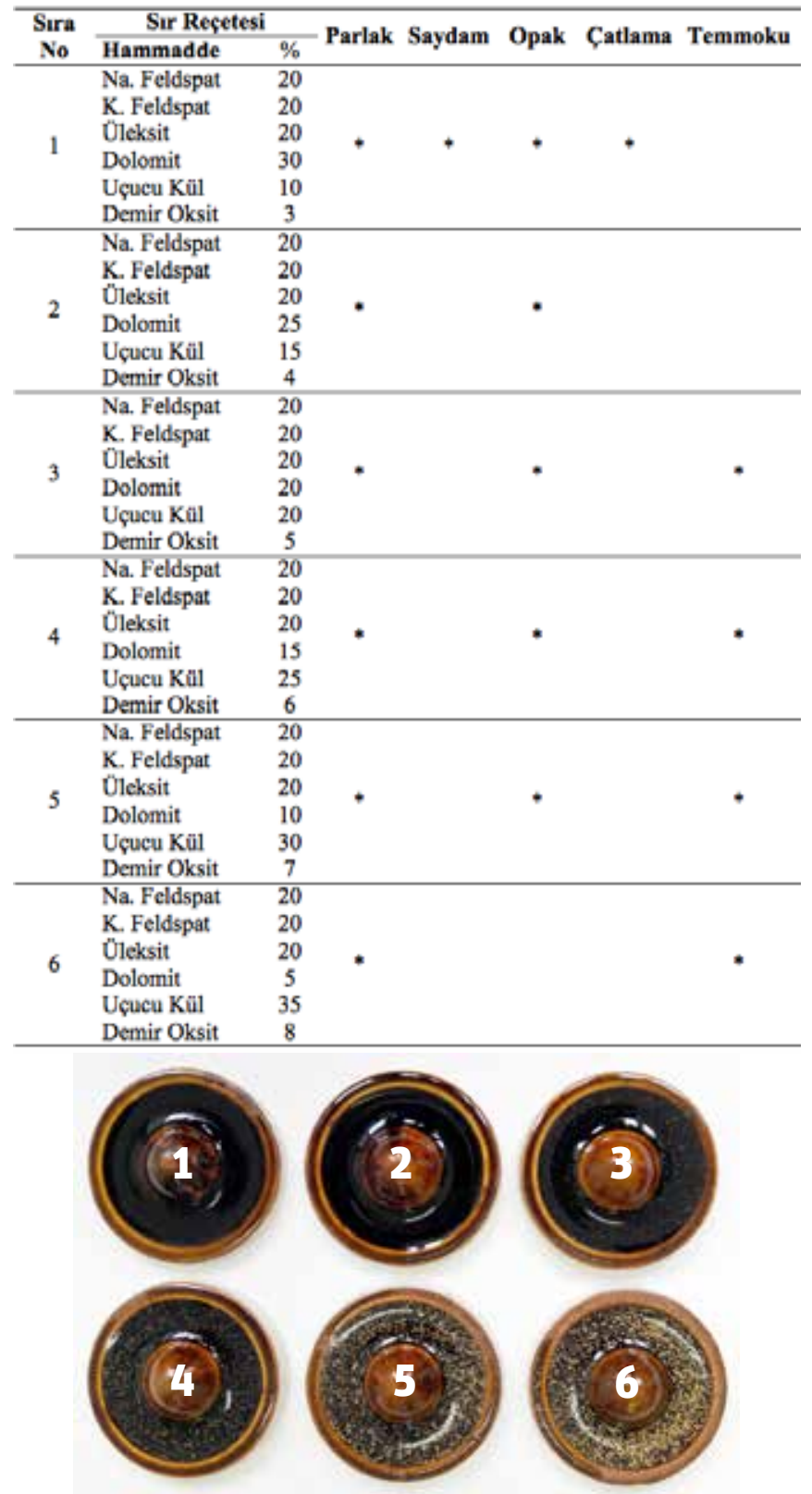

Resim 3. Uçucu Kül-Demir Oksitli Temmoku Sırların Pişirme Sonrası Görsel Sonuçları

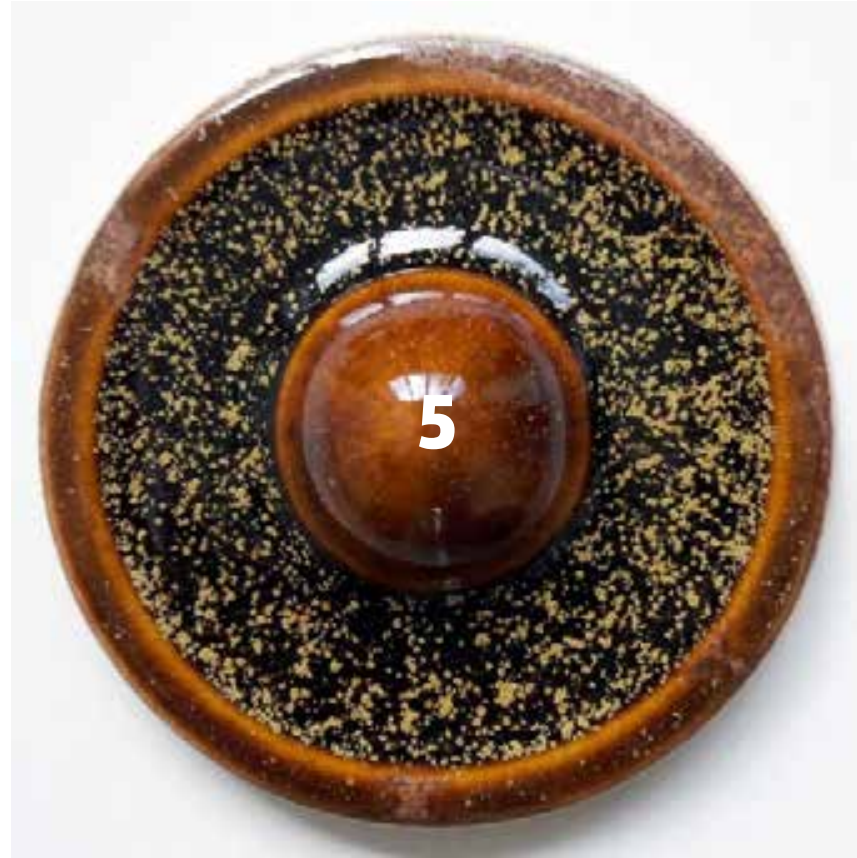

Resim. 5 Nolu Sıra Ait Görsel Detay

Tablo 2'de yüzey özellikleri, Resim 3'de oksidasyonlu pişirim ortamında görsel sonuçları verilen uçucu kül-demir oksitli temmoku sırlar incelendiğinde pişirime sonrası uçucu kül miktarının \% 20’nin altında kullanıldığı sırlar temmoku özelliği göstermemiştir. Sır bileşiminde uçucu kül miktarının \% 20’nin üzerine çıkmasıyla sırlar temmoku özelliği kazanmıştır. Uçucu kül miktarı ve demir oksit miktarı arttıkça sır yüzeyinde benekler daha da yoğunlaşmıştır. Dik yüzeylerde sırın davranışını gözlemek için 5 nolu sır çoğaltılarak sırlanmış vazo Resim 7'de verilmiştir.

\subsection{Uçucu Kül İlaveli Temmoku Sırlar}

Uçucu külün temmoku sır özelliklerine etkilerini araştırmak amacıyla hazırlanan "Uçucu Kül İlaveli” temmoku sırların reçete bileşimi ve yüzey özellikleri Tablo 3’te, 1200 oC'de pişirme sonrası görsel sonuçları Resim 5'de ve 2 nolu sıra ait görsel detay Resim 6’da verilmiştir. 
Tablo 3. Uçucu Kül İlaveli Temmoku Sırların Reçete ve Yüzey Özellikleri

\begin{tabular}{|c|c|c|c|c|c|c|c|}
\hline \multirow{2}{*}{$\begin{array}{l}\text { Sura } \\
\text { No }\end{array}$} & \multicolumn{2}{|c|}{ Sir Rocetesi } & \multirow{2}{*}{ Parlak } & \multirow{2}{*}{ Saydam } & \multirow{2}{*}{ Opak } & \multirow{2}{*}{ Çatlama } & \multirow{2}{*}{ Temmoku } \\
\hline & Hammadde & $\%$ & & & & & \\
\hline \multirow{7}{*}{1} & Na. Feldspat & 45 & \multirow{7}{*}{$\cdot$} & & \multirow{7}{*}{ • } & \multirow{7}{*}{ * } & \multirow{7}{*}{ - } \\
\hline & K. Feldspat & 5 & & & & & \\
\hline & Ốleksit & 20 & & & & & \\
\hline & Dolomit & 20 & & & & & \\
\hline & Kuvars & 10 & & & & & \\
\hline & Uçucu Kâl & 10 & & & & & \\
\hline & Demir Oksit & 8 & & & & & \\
\hline \multirow{7}{*}{2} & Na. Feldspat & 45 & \multirow{7}{*}{$\cdot$} & & & \multirow{7}{*}{ • } & \multirow{7}{*}{ • } \\
\hline & K. Feldspat & 5 & & & & & \\
\hline & Oleksit & 20 & & & & & \\
\hline & Dolomit & 20 & & & & & \\
\hline & Kuvars & 10 & & & & & \\
\hline & Uçueu Kal & 15 & & & & & \\
\hline & Demir Oksit & 8 & & & & & \\
\hline \multirow{7}{*}{3} & Na. Feldspat & 45 & \multirow{7}{*}{$\bullet$} & & \multirow{7}{*}{ 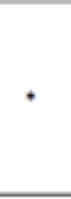 } & & \multirow{7}{*}{ * } \\
\hline & K. Feldspat & 5 & & & & & \\
\hline & Ôleksit & 20 & & & & & \\
\hline & Dolomit & 20 & & & & & \\
\hline & Kuvars & 10 & & & & & \\
\hline & Uçucu Käı & 20 & & & & & \\
\hline & Demir Oksit & 8 & & & & & \\
\hline \multirow{7}{*}{4} & Na. Feldspat & 45 & \multirow{7}{*}{ • } & & \multirow{7}{*}{+} & & \\
\hline & K. Feldspat & 3 & & & & & \\
\hline & Oleksit & 20 & & & & & \\
\hline & Dolomit & 20 & & & & & * \\
\hline & Kuvars & 10 & & & & & \\
\hline & Uçucu Käl & 25 & & & & & \\
\hline & Demir Oksit & 8 & & & & & \\
\hline & Na. Feldspat & 45 & & & & & \\
\hline & K. Feldspat & 5 & & & & & \\
\hline & Oleksit & 20 & & & & & \\
\hline 3 & Dolomit & 20 & • & & * & & * \\
\hline & Kuvars & 10 & & & & & \\
\hline & Uçucu Kül & 30 & & & & & \\
\hline & Demir Oksit & 8 & & & & & \\
\hline & Na. Feldspat & 45 & & & & & \\
\hline & K. Feldspat & 5 & & & & & \\
\hline & Oleksit & 20 & & & & & \\
\hline & Dolomit & 20 & . & & . & & . \\
\hline & Kuvars & 10 & 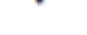 & & & & \\
\hline & Uçucu Kũl & 35 & & & & & \\
\hline & Demir Oksit & 8 & & & & & \\
\hline
\end{tabular}

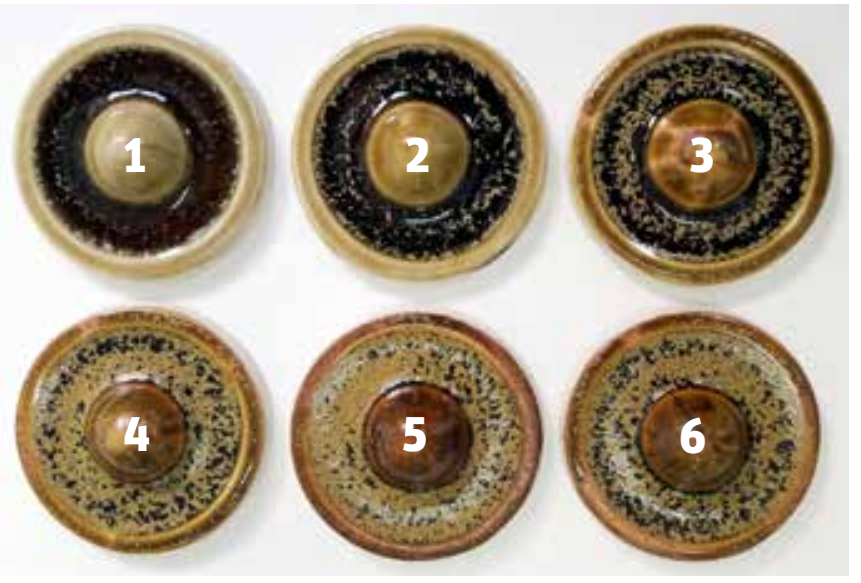

Resim5. Uçucu Kül İlaveli Temmoku Sırların Pişirme Sonrası Görsel Sonuçları

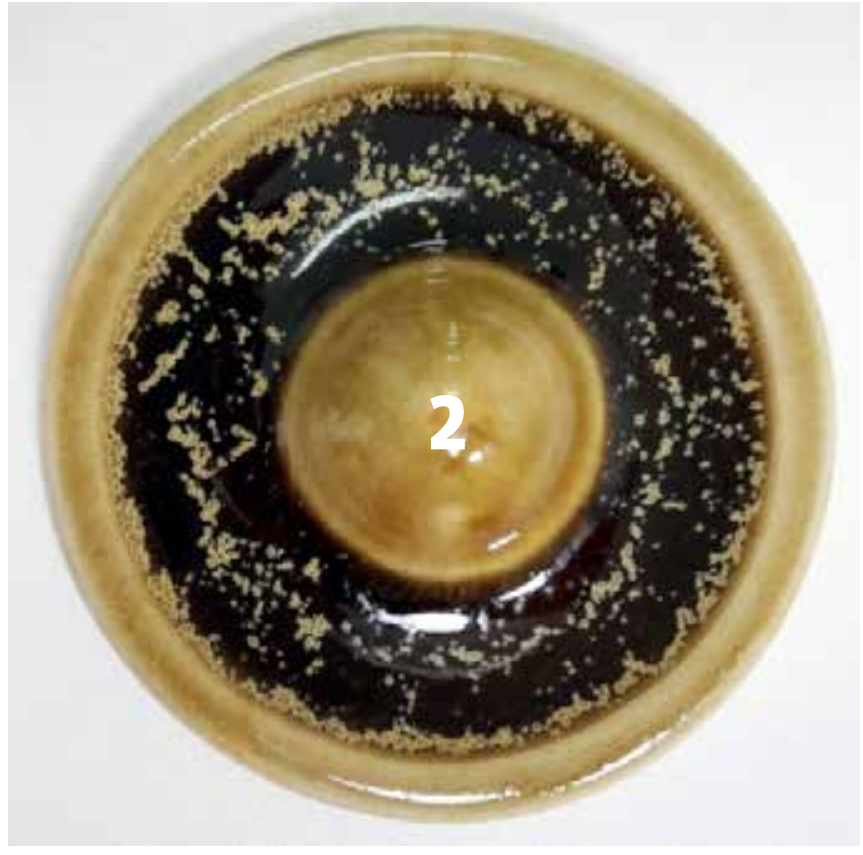

Resim 6. 2 Nolu Sıra Ait Görsel Detay

Tablo 3'te yüzey özellikleri, Resim 5'de oksidasyonlu pişirm ortamında görsel sonuçları verilen bu sırlar incelendiğinde pişirime sonrası uçucu kül miktarının kademeli olarak arttırıldığı tüm sırlar temmoku özelliği göstermiştir. Uçucu kül miktarının \% 20’nin altındaki sırlarda beneklenmelerin daha az olduğu, bu oranın üzerindeki sırların yüzeyinde ise beneklerin daha da yoğunlaştığı gözlenmiştir. Dik yüzeylerde sırın davranışını gözlemek için, 2 ve 5 nolu sırlar çoğaltılarak sırlanmış bardaklar Resim 8'de verilmiştir.

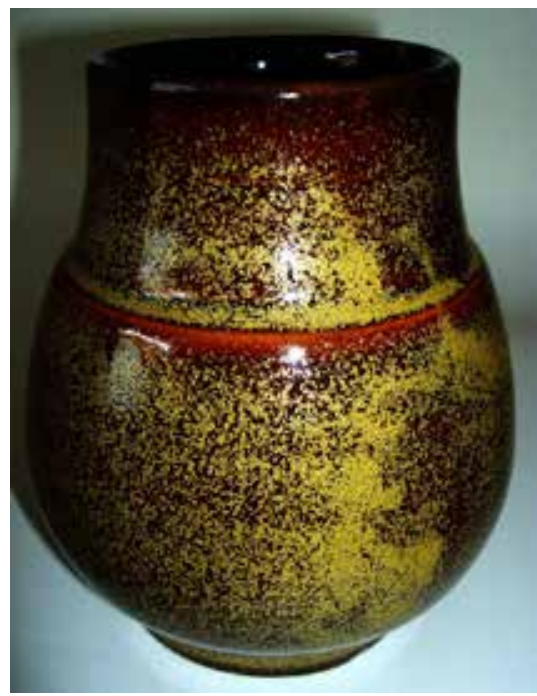

Resim7. Temmoku Sırlı Seramik Vazo 
YEDI: SANAT, TASARIM VE BILIM DERGIS I

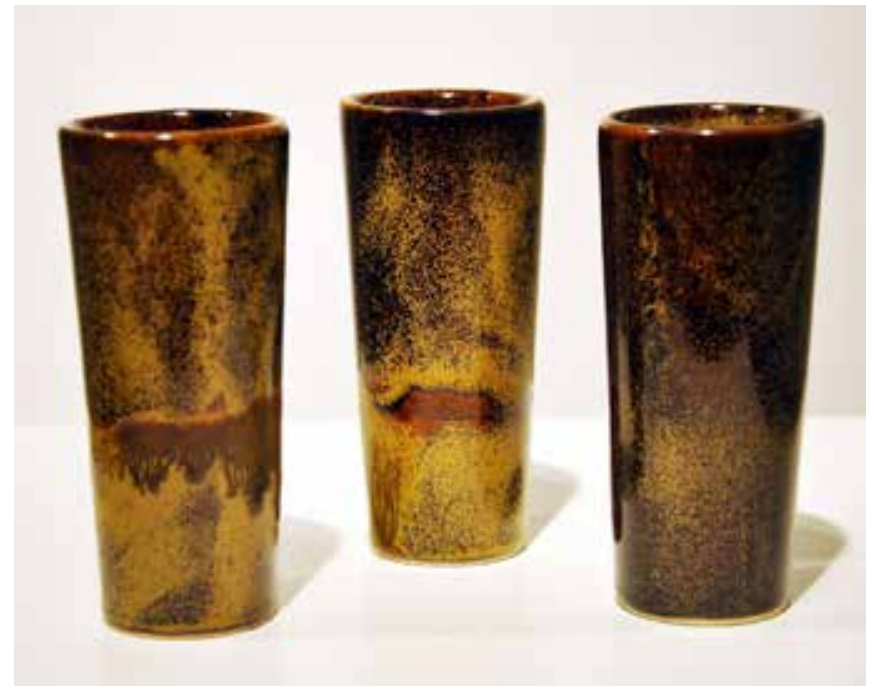

Resim 8. Temmoku Sırlı Seramik Bardaklar

\section{Sonuç}

Genel olarak Seyitömer termik santral uçucu külü temmoku sırlarda artan oranlarda kullanıldığında oksidasyonlu pişirim atmosferinde, kahverengi ve siyah zeminli benekli temmoku sırlar elde edilmiştir.

Uçucu kül - demir oksitli temmoku sırlarda pişirime sonrası, uçucu kül miktarının \% 20'in altında olduğu sırlar temmoku özelliği göstermemiştir. Sır bileşiminde uçucu kül miktarının \% 20'nin üzerine çıkmasıyla sırlar temmoku özelliği kazanmıştır. Ayrıca dolomit miktarının azaltılıp, uçucu kül miktarı ve demir oksit miktarı arttıkça, demir oksit kristallerinin sır yüzeyine taşınarak çökmesi nedeniyle, sır yüzeyinde çok yoğun benekler oluşmuştur.

Uçucu kül ilaveli temmoku sırlarda pişirme sonrası, uçucu kül miktarının kademeli olarak arttırılması sonucunda tüm sırlar temmoku özelliği göstermiştir. Uçucu kül miktarının \% 20'nin altındaki sırlarda beneklenmelerin daha az olduğu, bu oranın üzerindeki sırların yüzeyinde ise beneklerin daha da yoğunlaştığı gözlenmiştir.

Geleneksel temmoku sırları genellikle 1280 oC'de ve üzeri sıcaklıklarda ve $10-12$ saat pişirim süresi sonucunda elde edilmiştir. Bu çalışmada ise temmoku sırları 1200 oC'de ve 7- 8 saat pişirim süresi sonucunda elde edilmiştir. Geleneksel temmoku sırların elde edilmesinde yer almayan uçucu külün bu sırlarda alternatif bir hammadde olarak \% 35 oranında kullanılabileceği belirlenmiştir. Ayrıca, uçucu külün yüksek oranda demir oksit içermesi ve tane boyutu $200 \mu \mathrm{m}$ altında olması, kullanım öncesi öğütülme işlemi gerektirmemesi, temmoku sırların üretim maliyeti açısından bir avantaj sağlamaktadır.

\section{Kaynakça}

Ilic, M. Cheeseman, C. Sollars, C. Knight, J. (2002). “Minerology and Microstucture of Sintered Lignite Coal Fly Ash". Elsevier, (82)331-336

Karasu, B. Kaya, G. Aydasgil, A and Kurama, H. (2004). "Use of Tuncbilek Thermal Plant's Fly Ash in Stoneware Glazes as Coloring Agent". Key Engineering Materials Vols. (264268)2501.

Kaya, G. Turan, S. (2004). "Yüksek Fırın Cürufunun Seramik Sektöründe Katma Değeri Yüksek Ürünlerin Eldesinde Değerlendirilmesi”. Mühendis ve Makine, 45(536)48.

Maitra, S. (1999). “Ceramic Products from Fly Ash: Global Perspectives". Flay Ash Utilisation for Value Added Products Eds. B. Chatterje, K.K. Singh\& N. G. Goswami, NML, Jamshedpur, 32.

Mishulovich, A. and Evanko, J. L. (2003). "Ceramic Tiles from High-Carbon Fly Ash". International Ash Utilization Symposium, University of Kentucky, 1.

Naoyuki, F. (1982). "Magnetite in Yuteki-Temmoku (oil-spot) Glaze”. Bulletion of Kanazawa College of Art, (26)66.

Peterson, S. (2004). Shoji Hamada, A Potter's Way-Work, UK.

Shah, H.M., Maiti, K.N. (2001). "Development of Glazed Walll Tiles Through Optimal Utilization of Fly Ash”. Transactions of the Indian Ceramic Society, 60(3)145-147.

Topçu. İ.B. Canbaz, M. (2001). “Uçucu Kül Kullanımının Betondaki Etkileri”. Eng. Arch. Osmangazi University, Vol.14(2)12.

Weidong, L. Hongjie, L. Jianan, L. Jiazhi, L. and Jingkun G. (2008). "Studies On The Microstructure Of The Black-Glazed Bowl Sherds Excavated From The Jian Kiln Site Of Ancient China". Ceramic International, 6(34)1474.

Wills, B.A. (1981). Mineral Processing Technology, U.K.

Zimmer, A. Bergaman, C.P. (2006). "Flay Ash of Mineral Coal as Ceramic Tiles Raw Material”, Elsevier , (27)62 http://www. kutahyacimento.com/(11.06. 2017). 


\title{
Yok Olan Yazar, Var olan Seyirci: Tim Crouch The Author
}

\author{
Mesut GÜNENÇ*
}

Özet

Yirminci yüzyılın ikinci yarısı Edward Bond, Mark Ravenhill ve Sarah Kane gibi oyun yazarlarının farklı ve şok edici trajedilerini içeren Suratına Tiyatro döneminin etkisi altındadır. Çağdaş İngiliz oyun yazarlığı bağlamında Martin Crimp, Simon Stephens ve Tim Crouch'un oyunlarıyla, sözsel ve politik tiyatro yirmi birinci yüzyılın ilk zamanlarında yerini almıştır. Ünü hem Britanya hem de Avrupa’ya yayılan, en önemli çağdaş oyun yazarlarından biri olan Tim Crouch, deneysel ve postdramatik türdeki oyunları ile birlikte çağdaş İngiliz tiyatrosuna çok büyük ölçüde katkı yapar. Bu çalışma, Tim Crouch'un şiddet içeren, şok ve rahatsız edici The Author (Yazar) oyununu çağdaş tiyatroda aktif sorgulama, seyirci katılımı, tepkisi ve sorumluluğu bağlamında ele almaktadır. Oyun, çağdaş performansta ses ve konuşmaların farklı kullanımlarını sorunsallaştırmak için seyirci deneyimi ile ilgili kritik bir bağlantı sunmaktadır. Bu çağdaş performans Roland Barthes’ın terminolojisi ve ünlü nitelemesi “Yazarın Ölümü”ne gönderme yaparak seyircinin aktif katılımını amaçlamakta ve sorumluluğunu anımsatmaktadır.

Anahtar Sözcükler: Tim Crouch, The Author, Yazarın Ölümü, Aktif Katılım.

\section{Disappearing the Author, Appearing the Audience: Tim Crouch The Author}

\section{Abstract}

The second part of the 20th century has been placed influenced by In-your-face Theatre, which includes different and shocking tragedies of forefront playwriters such as Edward Bond, Mark Ravenhill and Sarah Kane. In the beginning of the 21st century, verbal and political theatre have been been predominant thanks to the plays of contemporary British play writers like Martin Crimp, Simon Stephens and Tim Crouch. Tim Crouch is an important contribution to contemporary British theatre with his experimental and post dramatic plays. This study discusses Tim Crouch's violent, shocking and disturbing play, The Author (2009), in the context of active questioning, audience participation, response and responsibility in contemporary theatre. It presents a critical engagement with spectator experience in order to problematize different uses of voice and speech in contemporary performances. Using Roland Barthes's terminology and famous definition "The Death of the Author", this contemporary performance aims to achieve audience participation and evoke his/her responsibility.

Keywords: Tim Crouch, The Author, Death of the Author, Active Participation. 


\section{Giriş}

Tim Crouch yirmi birinci yüzyıl Çağdaş İngiliz Tiyatrosunda yer alan en özgün oyun yazarlarından biridir. Crouch, Bristol Üniversitesi'nde drama eğitimi alır ve burada Grotowski çalışmalarına bağlı olarak deneysel tiyatro üzerine çalışmalarda bulunur. Çağdaş İngiliz tiyatrosunun en yenilikçi oyun yazarlarından Tim Crouch İngiltere dışında Avrupa'da da çok şöhretli bir oyun yazarı olarak bilinir. Bottoms, Crouch'un bu durumunu şu şekilde ifade eder: "İngilizce oyun yazarlığının yirmi birinci yüzyıldaki en önemli yapı taşlarından birini oluşturmaktadı" (Bottoms, 2011: 11). Crouch eşi Julia ile birlikte 1982 yılında Public Parts adında bir şirket kurar. Public Parts daha deneyimsel metotların uygulandığı, tiyatroyu tiyatroyla tanışmayan yerlere götüren, toplumu tiyatroyla buluşturan bir oluşumdur (Radosavljevic, 2013: 216).

Crouch sahnelemenin her aşamasında yer alır, aktörlük yapar, doktoraya başlar yarıda bırakır, tiyatronun seyirci ile var olma ilişkisi üzerinde durur, National Theatre'da çalışır, çıraklık dönemini burada geçirir ve ilk oyununu otuz sekiz yaşında yazar. Çağdaş İngiliz tiyatrosuna getirdiği yenilikler, toplumsal sorunlara duyarlı olma ve kullandığı dil ile İngiltere ve Avrupa'da hem genç yaştaki seyirciler hem de yetişkinler tarafından rağbet görür. Crouch İngiltere'de daha çok yenilikçi ve kuralları alt üst eden oyun yazarı olarak tanınır. Dan Rebellato, Crouch'un özellikle yenilikçi ve sorgulayan tarafını şu sözlerle doğrular:

Tim Crouch, bütün yapıtları tiyatroyla, oyunlarla ve performansla; dünyayla ve birbirimizle olan ilişki türlerimiz hakkında araştırıcı sorular soran bir oyun yazarı ve oyuncudur. Oyunları ve bu oyunlardaki performansları çok sıkı bir bütünlüğe sahiptir. Oyunların ortaya koyduğu oldukça ilginç bulmacalar ve sorduğu soruların kimisi, onun kendi teatral performansından kaynaklanmaktadır (Rebellato, 2013:125-126).

Bugüne kadar Crouch on bir oyun üretmiştir. Yetişkin izleyenler için yazdığı dört oyun -My Arm (2003), An Oak Tree (2005), ENGLAND (2007) ve The Author (2009)-yanında Crouch ayrıca genç yaştaki izleyenler için Shooping for Shoes (2003) ve Kaspar the Wild (2006) oyunlarını yazar. Ayrıca Shakespeare'in önemli oyunlarındaki önemsiz/ikincil durumda kalmış karakterleri ele alan, genç izleyenlere hem Shakespeare'i anlatan, hem de 'bu karakterler oyunlarda devam etmiş olsalar nasıl reaksiyon verirler' sorularını cevaplamak isteyen I Shakespe- are başlıklı toplu oyunları yazar. 2011 yılında toplu baskısı yapılan I Shakespeare başlıklı oyunlar sırasıyla I Malvolio (Ben Malvolio), I Banquo (Ben Banquo), I Caliban (Ben, Caliban) ve I Peaseblossom (Ben Peaseblossom)'dur. Bu oyunlara bir yıl sonra I Cinna (The Poet) (Ben Cinna) oyununu ekler. Bu çalışmalarda Shakespeare'in daha çok bilinen beş oyunu (Twelfth Night, Macbeth, The Tempest, A Midsummer Night Dream, Julius Caesar) daha az tanınan karakterlerle yeniden anlatılır.

Özellikle son oyunları (England, The Author ve I Shakespeare) ile birlikte Crouch'un esas amacı tiyatroyu seyircinin sesini duyurabileceği bir yer olduğunu göstermektir. Crouch tiyatroda performansın seyirci üzerinde nasıl bir etki bıraktığını göstermek ister. Bu yüzden "sahne yönergelerini en aza indirirken seyirci alanı ve katılımını en üst derecede gerçekleştirmek ister" (Bottoms, 2011: 69). Michael Fried izleyici etkileşiminin önemini vurgulamak için diğer sanat dallarının aksine "tiyatronun seyircisi vardır ve bu yüzden var olur" ifadesini kullanır” (1998: 140).

The Author adlı oyunun yapı ve içeriği düşünüldüğünde yazar ve diğer oyuncular, seyirci reaksiyonlarının yeniden şekillendirilmesini amaçlar. Seyirci reaksiyonlarını gözlemlemek, seyirci etkileşiminin nasıl gerçekleştiğini ve ne derecede aktif katılımın sağlandığını anlamak için bu çalışmada öncelikle oyun incelenecek ve daha sonraki bölümde Roland Barthes'ın Yazarın Ölümü (1977) ve okunabilir (readerly) ve yazılabilir (writerly) metin kavramları ile oyunun analizi yapilacaktır.

\section{The Author}

The Author 2009 yılında yayımlandıktan sonra hem basında hem de akademik ortamda oyun hakkında ciddi anlamda eleştiriler yapılmaya başlanmıştır. Bob Verini, Tim Crouch'u “teatral deneyimin kışkırtıcı bir yapı bozumcusudur” (2011) sözleriyle tanımlarken Cavendish oyunu "birçok tiyatro eserinin aksine The Author, oldukça taşlayıcı ve soğukkanlı biçimde kışkırtıcı" (2009) sözleriyle; Mcmillan (2011) oyunu "zekice başarılı, ahlaki sorumluluk ve keşif hissi uyandırıcı" şeklinde tanımlar. Carole Woddis ise performansı "samimi, hazırlıksız yakalayan ve oldukça ahlaki” bulur ve performansın esas amacının, Crouch'un kendini “bir erkek yaratıcı ve tacizci olarak en sorumlu yere koyarak, günümüz teknolojisiyle birlikte taciz potansiyelinin arttığını göstermek” (2009) olduğunu belirtir. Aleks Sierz "Crouch bize canlı performansın risklerini hatırla- 
tır ve performansı sergileyenler ve izleyenler arasındaki geleneksel bölmeleri sorgular" (2009) ifadesiyle oyunun ortaya koymaya çalıştığı yeniliği işaret eder. Lyn Gardner, Crouch'un oyunundaki seyircilerin sorumluluğunu "kendi imgelerini canlandırmaları için hayal güçleriyle oyuna dâhil olmaları gereken işbirlikçilerdir” (2009) şeklinde açıklar. Crouch eleştirmenlerin görevinin oyun hakkındaki tartışmayı otoriter bir şekilde sonlandırmak değil aksine oyun hakkında daha fazla tartışmanın olmasını sağlamak olduğunu düşünür. Bu görev seyirciler için de deneysel tiyatroda istenilen bir eylemdir. Böylelikle hem oyuncular hem yazar hem de seyirciler çağdaş görünen ama tamamen yozlaşan dünyada kendi sorumluluklarının farkına varırlar.

Farklı teoriler, söylemler ve eleştiriler olmasına rağmen oyun, genel anlamda, çağdaş tiyatro örneklerinde sağlam bir yer edinir. Sarah Kane'in ilk oyunu Blasted'tan on beş yıl sonra sahnelenen oyun, günümüz sorunsallarına değinmesiyle ve ayrıca Suratına Tiyatro akımına katkısıyla ve klasik metin anlayışını yapı bozumuna uğratmasıyla çağdaş oyun örnekleri ile benzerlik gösterir.

23 Eylül 2009'da Royal Court Tiyatrosu Jerwood Theatre Upstairs'de sahnelenen The Author (Yazar) oyununda Crouch, yazıp yönettiği ve oynadığı, babanın kızına şiddet içeren, cinsel istismar uyguladığı kurgusal bir öyküyü anlatır. The Author Royal Court'ta şiddeti sahneleyen bir oyundur. Oyunda sahnelenmeyen ama sözlerle aktarılan şiddet kavramı mevcuttur. Şiddeti tiyatroda sahnelemek gerçekten zordur. Look Back in Anger (1956) oyunuyla başlayan, 1990’lardaki şiddet temalı oyunları tüm içtenlik ve çıplaklığıyla sahneleyen ve seyircileri dört duvar arasından çıkarıp dış dünyanın tüm gerçekliğiyle anlatılmasına izin veren Royal Court Theatre Tim Crouch'un oyunu için en uygun mekandır:

The Author başka bir oyunun öyküsünü anlatır: Royal Court Jerwood Theatre Upstairs'de sahnelenen ve Tim Crouch adında bir oyun yazarı tarafından yazılan, şiddet içeren, şok ve taciz edici bir oyun. The Author, biri oyunu yazan oyun yazarı diğeri de oyunu izleyen seyirci olarak iki oyuncunun yer aldığı bir etkileşimi planlar. Oyun, ayrıca şiddet imgelerine doymuş böyle bir oyunun yazılabildiği daha geniş çaplı bir dünya ile etki bırakması için medya tarafından çarpıtılmış bir dünya arasında bağlantı kurar. Oyun ayrıca hem sanat hem de günlük yaşantıda bu ihtiyacın sonuçlarını araştırır (An Article by Tim Crouch).
Crouch “Edward Bond'un Saved oyununda bir bebeğin taşla öldürülmesi, Sarah Kane'nin Blasted oyununda ölü bir bebeğin yenilmesi” (Crouch, 2011b: 417) gibi sahnelenen oyunlardan örnekler vererek bu uygunluğu genel anlamda açıklar. Kendi oyununda ise bu durumu Adrian'ın tanıklığı ile destekler:

Burası dünyanın en güvenilir yeri! Siz öyle düşünmüyor musunuz? Geliyorum buraya, rahatsızlanıyorum, çöküyorum burada. Burada her şey olabilir mümkündür ve güvenlidir. Burada hayal edebileceğiniz her şeyi gördüm. Burada anal seksi ve kıç yalamayı ve oral seksi ve mastürbasyonu ve tecavüzü ve bıçaklamayı ve cinayeti ve bombalamayı gördüm. Birinin masaya sıçtığını gördüm! Adamın gözlerini oydurttuğunu gördüm. Birçok insanın kör edilişini. Ve taşlamaları. Bir çantada ölü bir bebek gördüm. Ölene kadar taşlanan bebek. Ölü bir bebeğin yendiğini gördüm. İnanılmazdı (Crouch, 2011a: 192).

Royal Court tiyatrosu 50 yıllık süre zarfında Adiran'ın belirtmiş olduğu bu sahne kesitlerini, çok önemli ve yenilikçi oyun yazarları ve aykırı çağdaş dönem oyunlarıyla seyircilere aktaran yer olmuştur. Royal Court tiyatrosunda yer alan şiddet imgelerine paralel olarak Tim Crouch The Author'da çocuk pornosuyla sunulan cinsel istismarı ele alır. "Crouch The Author'da, uç boyutlardaki şiddet olgusunu ve ensest ilişki biçimlerini günlük hayatın bir parçası olarak sunan aşırı doğalcı ve toplumsal gerçekçi tiyatroyu eleştirerek günümüzün yadsınamaz gerçeği olan şiddeti dil düzeyiyle sınırlandırır” (Biçer, 2016: 164). Bu gerçekler, cinsel istismar ve şiddet sahne dışında yer alır. Royal Court, sanat aracılığıyla istismarı, şiddeti kısacası toplumsal gerçekleri seyircilere sunan merkezdir.

Tim Crouch, oyunu kendisinin oynadığı Tim, Esther Smith'in oynadığı Esther, Vic Llewellyn'in oynadığı Vic ve izleyici olarak yer alan Adrian Howells, Adrian karakterleriyle sahneler. Rol alanlar izleyenler arasında oturur. Son çalışması The Author'da sahneyi ortadan kaldırır ve seyircileri karşılıklı olarak oturtur, onları yüz yüze getirtir. Bu oyunda oyun yazarı aynı zamanda aktör olarak karşımıza çıkar. Tim Crouch bir seyirci gibi belirgin bir konumda izleyenler arasında yer alır. Aynı zamanda oyunun performans süresince izleyenler arasına karışmış oyuncular da gözlemlenmektedir. Oyun yazarı ve oyuncuların hepsi seyircilerin arasında seyircilerle birlikte hem gözlemleyen hem de anlatan konumundadırlar. Crouch kasıtlı olarak konuşmalarda aktörleri oynadıkları karakterler- 
den ayırır. Kurgusal bir oyunun kurgusal anlatımında, seyirci, yazar ve oyuncular kendi gerçek isimlerini kullanırlar. Böylelikle “iki farklı dünya (Tim Crouch'un gerçek dünyası, The Author'un yazarı, Tim Crouch'un kurgusal gerçekliği, kurgusal oyunun istismarcı yazarı)" (İlter, 2011: 397), birbirinden ayrılamaz duruma gelir.

Geleneksel sahne sistemi olmaksızın birbirlerini izleyen seyirciler ve rol alanlar karşılıklı reaksiyonlarını gözlemlerler. Crouch'un esas amaçladığı şey "seyircinin kendisiyle yüzleşebileceği bir çalışma”dır (Radosavljevic, 2013: 222). The Author oyunundan önce Crouch benzer izleyici katılımına England oyununda da yer verir: "birbiri içine geçen bir oyun, başkasının bedeninde yer alan bir kalp, başka kültürle bütünleşmiş olan bir kültür, galeri içinde tiyatro, bir aktör içinde bir karakter, seyirciler içinde bir oyun" ("England by Tim Crouch”). England oyunu bir galeride sahnelenir. Crouch ve Hannah Righman seyircileri karşılar ve sergideki sanat çalışmasını onlara sunarlar.

Öte yandan The Author, England oyununun aksine seyircilerin her birini birey olarak kabul eder ve onları ismi ile çağırır. Her izleyenin reaksiyonu farklılı gösterebilir. Crouch bu farklılığı "biz aslında komik olmayan şeylere gülerek ve komik olanlara üzülerek farklı reaksiyon gösterebiliriz" (Bottoms, 2011: 18) şeklinde anlatır. The Author'da oyun içinde oyun kavramı gözlenir. Seyircilerde oyunun her evresinde katılımlarının sağlanması istenen karakterlerdir.

Oyunun başında seyirciler ve oyuncular arasında değişim ve etkileşimin olacağı belirtilir: "oyunda samimi ve rahat yerler olması gerekir. İzleyenler güzel bir şekilde ağırlanmalı ve aydınlanmalıdır. Soru sorulduğunda, seyircinin direk cevap verebileceği sorular olmalıdır. Fakat bunu zorlayacak hiçbir baskı olmamalıdır” (Crouch, 2011a: 164). Bunu gerçekleştirmek için oyunun başında bir seyirci olarak görülen Adrian, birlikte oturduğu seyircilerle direk iletişime geçme çabasındadır bu yüzden bu performanstan beklentisini açıklar ve seyircilerin isimlerini sorgular. Henüz oyunun başında Adrian'ın direk sorular sorması ve sorgulaması seyirciler üzerinde bir şok etkisi yaratır:

(...) Adınız nedir? Bunu seviyor musunuz, ----?

Dizlerimiz birbirine değiyor! Yanındakinin kim olacağını bilmiyor musun?

Ben yanındayım! Adınız nedir?
Bu güzel. Siz güzelsiniz! Güzel değil mi? Herkes?

Şimdi çenemi kapatacağım. Duracağım (Crouch, 2011a: 165).

Adrian sorduğu sorularda tekrara başvurarak seyircinin cevap vermesi için teşvik etmeye çalışır:

Biz ne yapıyoruz, merak ediyorum, siz biliyor musunuz?

İyi fikir, değil mi?

Değil mi? (166).

(...)

Her zaman umut vardır, değil mi?

(...)

Siz umutlu musunuz? Sizin umudunuz nerde?

Bakın bize. bizim yalnız, umutlu kalplerimize bakın!!

Burada oturup bakıyorsunuz, bir şeyler olacak diye umut ediyorsunuz (Crouch, 2011a:168).

Oyunun öyküsü oyuncular tarafından seyircilerin arasında rahatsız edici bir dil ve sözcükler kullanılarak anlatılır. Bu durumda seyirciler öyküde tasvir edilen şiddeti ve istismarı hayal etmeleri için zorlanırlar ya da ayağa kalkarlar ve salonu terk ederler.

Oyunun sahnelenmesinin başından itibaren Crouch bu eserinde tiyatro kurallarını alt üst etmeye kararlı olduğunu gösterir. İzleyiciler de hem alışık olmadıkları durumla hem de postdramatik özelliklerden "sıcaklık ve soğukluk" (Lehmann, 2006: 89) öğesiyle karşı karşıya kalmışlardır. Crouch, dramatik tiyatro özelliklerine, alışılagelmiş karakter yapısına ve konu bütünlüğüne alışık olan seyirciye bütün bu özelliklerin yapı bozumuna uğradığını performans süresince göstererek soğukluk yaşatır ama aynı zamanda onları performansa dâhil ederek, onlara performansı sorgulatarak oyuna ısınmalarını sağlar.

Bu oyunda gerçek bir eylem değil sadece sözler mevcuttur. Bu konuşmalar gerçekten güçlü ve etkili konuşmalardır. Bu yüzden seyircilerin birbirleri ile olan etkileşimi çok önemlidir. Tim Crouch bu etkileşimin daha etkili olması için oyunun girişinde seyircilere "rahatsız edici imgeler ve konuşmaların olacağını, düzenli verilen aralarda seyircilerin kalmak isteyip istemeyeceğini sorguladık" ifadesiyle tamamen seyircilerin aktif katılımı olduğunu gösterir. Şiddet içerikli imgeler ve 
konuşmalar ve bunların seyircilere aktarılması Brecht'in epik tiyatrosuyla başlayan dramatik tiyatro geleneğinin sarsılması kavramını bir ileri boyuta taşımaktadır. Dramatik tiyatrodaki pasif seyirci tanımı Brecht'in epik formu ile birlikte zorlanmış, Brecht sonrası postdramatik dönemde çağdaş oyun yazarları ve özellikle Tim Crouch ile birlikte aktif seyirci kavramı ile yapı bozumuna uğramıştır. Tim Crouch bu yapı bozumunu oyunla ilgili şu sözleriyle ifade eder:

The Author izleyici olmanın anlamı ve izleyici olarak sorumluluklarımız hakkında bilgi veren bir oyundur. Oyun ne izlediğimiz ve ne yaptığımız arasındaki bağlantıyı araştırır. İzlemek için tercih ettiklerimiz hakkında sorumlulukları kaybettiğimizi hissediyorum. The Author bize bir şeyleri anlatmak için sadece sözcükleri kullanır, bazen bize sunulan bu sözcükler rahatsız edicidir. Çocuklar için değil izleyenler için bir oyundur (An Article by Tim (rouch).

İzleyenleri hem düşünsel hem de fiziksel yönden harekete geçirmek için oyuncuların sarf ettiği sözcükler hem rahatsız edici hem de şok edicidir. Vic özellikle bunu agresif bir şekilde uygular. Hem kendini sorgulayan hem de seyirciyi performansa dâhil olması gerektiğini şu sözleriyle açıklığa kavuşturur:

VIC. (...) En önemli şey kime konuştuğundur. Kime söylediğindir. Anlıyor musun? Sadece söyleyemezsin, oh, kendi kendime konuşuyorum. Ya da sesli düşünüyorum. Ya da bir 'tiyatroda' tek bir seyirciye anlatıyorum! Sadece seyircinin başının üstünde bir ampül yakıp, mesaj veremezsin! Sen, seyirciye senle ilişkili olan bir karakter yüklemek zorundasın. (...) Seyirciler için tehlikeli şeyler olmak zorundadır. Onlar belki de bir şeylere ikna olmak ya da razı gelmek ya da uyanmak ya da bir şeyleri kaydetmek zorundadırlar. Onları bir çocuk ya da bir itirafçı olarak hayal edin. Yardım etmek iyi bir şeydir. Ben size yardım ediyorum (Crouch, 2011a: 170).

Vic seyirciler arasında oturmaktadır ve bu sözleriyle oyuncuların görevinin sadece performans değil, kendisinin oyunda yer aldığı gibi seyircilerin kendi kimlikleri ile performansa dâhil olmaları gerektiğini açıklar. Seyirciler de oyuncular arasına karışmıştır. Yazar ve oyuncu yerini seyircinin aktif dönüşümüne bırakır. "The Author oyununun esas üzerinde durduğu konu, oyunun verdiği mesaj(lar)ı seyircinin kavrayabilmesi için yeterince çaba harcayıp harcamadığıdır. (...) Eğer oyun başarısız olursa bu sadece yazarın, ekibin, yönetmenin ya da metnin değil aynı zamanda seyircinin sorumluluğudur. Dinleme ve konuşma sadece nazik bir ricanın parçası değil aynı zamanda zorunlu bir tekliftir" (Angelaki, 2013:8). 'Ne düşünüyorsun" ifadesi ile seyircilerin konuşmasını ve katılımını destekleyen en iyi ifadedir. Crouch Brecht'in "seyircilere karar alma zorunluluğu getiren” (Willett, 2001: 37) epik tiyatrosuna yönelir. Fakat Brecht'ten farklı olarak “Crouch'un amacının seyirciyi eğitmek değil basit bir şekilde otorite ve sorumluluğu onların üzerine yüklemektir" (Radasovljevic, 2013:158).

Crouch mekân estetiği konusunu yenilikçi yöntemlerle yapı bozumuna uğratmış ve şüphesiz ki postdramatik türde en belirgin örneklerden birisini bizlere sunmuştur. 1990’larda şiddet içerikli oyunların aksine The Author daha fazla reaksiyon gösteren, düşünmek zorunda kalan aktif seyirci kitlesini hedefler. Crouch yaratıcı sahne tasarımı amaçlayan, aykırı duygular benimseyen, farklı seyirci kitlesini hedefleyen, postdramatik yani metne dayalı olmayan bir oyun ortaya çıkarır. The Author diğer oyunlarının aksine en çok ses getiren oyunu olmuştur. Çünkü yazar Yazar (The Author) adlı oyunda yazar olmasının yanında "oyuncu, seyirci, yönetmen, anlatıcı, arkadaş, koca ve sınırları yıkan gibi farklı roller ve sorumluluk" (Angelaki, 2013: 3) üstlenir. Bu şekilde hem gerçeği hem de kurguyu yansitmayı hedefler.

Crouch'un amacı Aristocu geleneğin bütünlük içeren yapısını değiştirip daha fazla ustaca kullanılan konuşmalara yer vererek performans aşamasında seyircinin katılımını amaçlar. Crouch, seyircilerin hayal gücünü daha aktif hale getirebilmek için oyunlarında "kategorileştirmeyi ve geleneksel anlatım tarzını reddeder" (Lane, 2010:140). Seyircilerin kısıtlanmış ve gelenekselleşmiş dramatik öğelerden sıyrılıp, düşünsel ve entelektüel taraflarını geliştirmelerini amaçlanır.

\section{The Author Oyununda Barthesci Etki}

Roland Barthes Fransız Post yapısalcılığın en güçlü temsilcilerinden biridir. Özellikle metinsel ve okuyucu odaklı yaklaşımlarıla eserlerin eleştirilmesinde ve okuyucu ve yazar arasındaki ilişkiyi irdelemesi ile Crouch'un eserine ışık tutar. Roland Barthes'ın The Death of Author (1977) ile okunabilir (readerly) ve yazılabilir (writerly) metin kavramları özellikle The Author oyununa rehberlik eder. Barthes dilin güçlü olmasını ve etki uyandırmasını ister. Kelimeler ve diyaloglar tek bir anlam içermemeli, metin kendi içerisinde farklı anlamlar 
barındırmalıdır. Barthes'ın görüşlerine paralel olarak Crouch bir yandan dilin dinamik gücünü yansıtırken bir yandan da kesintiler "(---.-)" ve suskunluklarla "(boşluk)” metindeki saklı kalan gücü seyircinin bulmasını amaçlar.

Dilbilim ve metinsel yaklaşımları analiz eden en etkili Fransız postyapısalcılardan olan Barthes, metinsel yaklaşımında okuyucu ve yazar arasındaki etkileşim üzerinde durur. Barthes "konuşmacı ya da yazarın metindeki gerçekliğinin ya da iddiasının farklı olsa bile gözlenen kesinlik ve gerçekliğin güçlü ve etkili bir dille yansıtılması taraftarıdır” (Allen, 2004: 98). Crouch ve diğer karakterler Barthes'ın istediği gibi dış dünyadaki gerçekliği sert ve şiddet içeren bir dille seyirciye direk yansıtmaktadırlar. Oyuna yazar ve seyirci arasında vahşeti ve yozlaşımı anlatan sert bir dil hâkimdir.

Crouch seyircilerin sadece oyunu izleyip ya da konuşmaları dinleyip gitmelerine izin vermez. Seyirci artık tüketici değil, metne tüm duyuları ile dâhil olan aktif katılımcılardır. Barthes bir edebi çalışmanın amacının okuyucuyu sadece bir tüketici değil aynı zamanda metnin üreticisi haline getirmek olduğunu belirtir. Böylelikle metin ve okuyucu/izleyici anlam üretme açısından aktif bir enerji ortaya çıkarır. Barthes özellikle yazılabilir metin (writerly text) üzerinde durur. Çünkü okunabilir metin okuyucuyu zorlamaz, farklı anlamlar üretmesi için talepte bulunmaz ve tüm okuyucu yazarın amaçlamış olduğu tek bir anlam üzerine odaklanır. Barthes bu durumun okuyucuyu zorlamadığını söyleyerek 'okunabilir metni' desteklemez ve 'yazılabilir metin' üzerinde durur (Barthes, 1974: 7) .

Crouch The Author oyununda Barthes'ın belirttiği gibi pasif bir seyirci profilini yapı bozumuna uğratmak ister ve metnin performansında seyirciye soru sorarak metnin yeniden anlamlandırılmasını amaçlar. Barthes'ın pasif okuyucu profiline karşı çıktığı gibi Crouch’ta seyircinin “oyunu izleyip çıkar giderim düşüncesini yıkmayı amaçlar. Seyircinin aktif katılımını en üst derecede zorlar. Barthes'a göre metni sadece okumak için okumak klasik yazarın amaçladığı bir şeydir ve bu okuyucuyu sıkmaktan başka bir anlam ifade etmez" (Hale, 2006: 240). Barthes'ın desteklediği yazılabilir metin okuyucuyu zihinsel anlamda zorlar ve kendi özgün anlamlarının ortaya çıkmasını sağlar. Diğer bir ifadeyle okuyucu metni kendi çıkarımlarıyla yeniden yazar. Crouch'un tiyatrosunda seyirciyazar, seyirci-oyuncu kavramları ile farklı anlamlar üretmek için seyirciler aktif çabaya zorlanır. Seyirci dramatik gelenekle yazılmış konu bütünlüğü olan metinlerin aksine, Crouch'un oyununda yer verdiği kesintiler ve konuşmalarla daha yaratıcı konumdadır. Sadece yazar ve oyuncu değil okuyucu ve izleyenler kendilerini gerçekleştirmek için yeni bir dil ve performans üretmekle yükümlüdür.

Barthes edebi bir çalışmanın amacını "okuyucuyu tüketici değil metnin üreticisi yapmaktır” (1974: 4) şeklinde açıklar. Çağdaş tiyatroda ise Crouch metne şekil veren ve yönlendirenin seyirci olması gerektiğini vurgular. Crouch oyuna 'sessizlik' ve 'boşluklar' içeren, "boşluk vurgulamaları çok sayıda ki seyirci isimlerini yansıtır” (Crouch, 2011a: 165) bölümler ekler. Bu eklemelerle seyircilerin oyuna katılmalarını, tutulmalarını ve anlam üretiminin bir parçası olmalarını amaçlar. Barthes "bir metin tek bir teolojik anlama sahip kelimeler dizisinden oluşmaz, metin birçok yazının birbiri içine geçtiği ve boğuştuğu çok boyutlu bir yerdir” (1977:146) şeklinde tanım yapar. "Yazar yazmaya başladığında kendi ölümüne adım atar” (142). Yazarın ölümü metaforik bir olgudur ve bu niteleme izleyicilerin aktif olarak anlam yaratma sürecine dahil olmaları sorumluluğunu anımsatır. Barthes yazarın sembolik çekilmesini şöyle ifade eder: "yazar ortadan kalktığında metnin şifresini çözmeye çalışmak nafiledir. Metne yeni bir yazar yüklemek, metni yeniden kısıtlamak, ona nihai bir anlam yüklemek ve yazmayı sonlandırmak anlamına gelir" (147). Performansta seyirciden istenilen birden çok çıkarım yapmasıdır, seyirci yazar olmadan, yazardan etkilenmeden, kendi yorumlarını bağımsız bir şekilde ortaya koyabilmelidir.

The Author oyununda izleyenler öyküyü yaratma ve öyküye katılım sürecinde aktif olarak görev almaları istenir. Barthes’a göre "metnin bütünlüğü kökeninde değil vardığı yerdedir" (148). Oyuncularla birlikte seyirciler konuşmalar ve sözcüklerle metnin orijinal halinden çıkıp oyun boyunca metne yeni öyküler ekleyerek yazarın konumunu sorgulamaya başlarlar. Oyunda oyuncular sorular sorularak ya da oyunculara sordurularak sürekli tartışma ortamı yaratılır, yaşadıkları toplumda neler olduğunu, nelerin yapılmadığını seyircilere aktarılarak onların da sorgulaması amaçlanır:

Ve kimse bilmiyor! Kimse bilmiyor!

Arabalar ve otobüslerle dışarıda dolaşıyorlar

ve hiçbiri hiçbir fikre sahip değil.

Tamamen hiçbir düşünce yok.

Biz buradayız, burada, güvendeyiz burada, 
(...) Siz de böyle düşünmüyor musunuz? (Crouch, 2011a:192).

Metinde güvenilir olamayan bir dil kullanılarak güvenilir olmayan toplum yansitılır. Bu toplumu performans sayesinde seyirci yargılar ve analiz eder. Crouch'un oyunu seyirciyi aktif çabanın içine çeker ve oyun yazarı gibi performansı anlam yüklemesi istenir. Bunu gerçekleştirmek için Crouch, oyuncular arasında sözsel çekişmelere ve oyuncuların da kendi varlıklarını sorgulamalarına başvurur. Bu çekişmede seyirciler sadece izleyen durumunda pasif olarak kalamazlar onların rahatsız olup performansa dahi olmaları beklenir:

Boşluk.

Esther: Bence oyunun çok başarılı ya da güçlü olma nedeni budur.

Seyirci bizim araştırma yaptığımızı görebildi, anladın demi,

Onlar inandı bize. Korku çok gerçekçi gözüktü.

Tiyatroyu tamamen sersemlemiş bir şekilde terk ettiler. Şok içinde Tim performans süresince ara sıra geldi.

Boşluk.

Vic: 0 oyunun beni değiştirdiğini söyledi. Ben onun bildiği adam değildim.

Tim: $\quad$ Yazıyorsun ve yazıyorsun ve keşfediyorsun ve keşfediyorsun. Ve izin veriyorsun. Seyircilere bırakıyorsun. Onlar kendi keşiflerini yapacaklar. Seyircilere birakiyorsun (Crouch, 2011a:190).

Crouch performans süresince Roland Barthes ise metin boyunca izleyenlerin, okuyanların ve karakterlerin aktif zihinsel katılımını talep ederler. Çünkü hem okuyucu hem de izleyen tek bir belirlenmiş anlamın dışına çıkmalıdır. Bunlar aynı oyun içinde farklı bir oyun/öykü sunularak ya da metin alt metinlerle desteklenerek ortaya çıkarılabilirler. Hem Barthes hem de Crouch için hem metin hem de performans sadece okunup/izlenmemeli, eleştirilmeli, sorgulanmalı ve çıkarım yapılmalıdır. Barthes eserde ‘yazarın ölümü’ olgusunu sorgularken Crouch kendi yarattığı performansta yazar olarak kendi otoritesini sorgulayarak yine kendini performans dışına iter ve oyunun performans limitini zorlar. Barthes'a göre okuyucu aktif ve üretken iken Crouch bu görevi hem oyunu okuyana hem de performans içinde aktif olarak yer alan seyirciye yükler.
Tim Crouch için yazar, oyuncu ve seyirci aynı duyguları paylaşmakta, aynı acıları ve sevinçleri yaşamakta ve aynı yerlerde yaşamaktadır bu yüzden hepsi birbirinden sorumludur ve seyirci ile oyuncu eşit seviyede olmalıdır. Performans süresince gerektiği yerde seyirci oyuncu, oyuncu ise seyirci olabilmelidir. "Yazar ya da oyuncu olarak yazılabilenler ya da sahnelenenler kısıtlı olabilirken bir seyirci için bu durum sorun değildir. Seyirci, aksine hem yazar hem de oyuncu yerine geçerek, onlara dönüşerek aktif rol oynar” (İlter, 2011: 395). Oyuncu sahnede bu dönüşümü yaşayabilir ama seyirci sözcükler, boşluklar, sessizlikler sayesinde performansı gözlemler hem de kendi gerçekçi dönüşümünü tamamlar. Böylelikle seyirci ayı zamanda hem oyuncu hem de yazar olarak performansta yerini alır. The Author oyununda oyuncular kendi isimleri ile kendilerini yansıtırlar. Ne Adrian ne de Vic oyun için ayrıca oyuncu durumunda değillerdir. Crouch onlardan sadece kendileri olmalarını ister. Eğer bir dönüşüm olacaksa bunu gerçekleştirecek olan seyircilerdir (İlter, 2011: 403).

Bu dönüşümün daha etkili olabilmesi için Crouch, The Author'un sonunda oyunun gösterimini kutlamak için oyuncularla birlikte akşam yemeğinde buluşur. Yemekten sonra onun haricinde herkes uyur alkollü bir şekilde bilgisayardan çocuk pornosu bulunan bir videoyu açar ve mastürbasyon yapar. Fakat videoyu kapatmayı bilgisayar geçmişini silmeyi unutur ve ertesi gün bu yaptığı ahlaksızlık fark edilir. Karısının ve kimsenin kendisini affetmeyeceğini söyleyerek boğazını keser. "Yazı yazarı terk eder" (Crouch, 2011a: 203) diyerek oyunu bitirir Barthes'ın “yazarın ölümü” nitelemesine gönderme yaparak ve "Tim tiyatro binasından dışarı çıkarak" (203) artık yorumlamanın, düşünmenin ve sorgulamanın izleyicide olduğunu anımsatır.

\section{Sonuç}

Crouch, Roland Barthes'ın “yazılabilir metin” ve "Yazarın Ölümü” olgularına gönderme yaparak, tiyatronun "güvenilir yer" kavramını da yapı bozumuna uğratır. Crouch'un başvurduğu konuşmalar, sessizlik, boşluklar ve öykü içeriği, seyircinin gerçek hayatta çektiği acıyı, deneyimlediği hatta deneyimlemediği ya da tanık olmadığı üzüntüyü tiyatroda canlı olarak yaşamasını sağlar. “Crouch'u çağdaşları arasında farklı kılan, tiyatroda seyirciyle olan ilişkinin geleneksel kalıplardan sıyrılarak yeniden düzenlenmesi ve gösterim sürecinde izleyicileri anlatan öyküye birer oyuncuymuşlarcasına dâhil etmesi şeklinde beliren bir düşünce yatar” (Biçer, 2016: 145). 
İzleyenlere çok önemli bir rol verilir. "Crouch, yazar-oyuncu, yazar-karakter olarak yer aldığı performansta dünya üzerinde yaşanılan, maruz kalınan şiddeti tiyatroya getirme görevini üstlenir" (White, 2013: 191). Bu görevi seyircilere aktarmak ister, bundan rahatsız olan seyirci oyun ortasında çıkıp gider ya da tanık olduğu oyunda kendi kişisel sorumluluğunun farkına varıp, aktif rol alarak bu görevi hakkıyla yerine getirir.

\section{KAYNAKÇA}

Allen, G. (2004). Roland Barthes. London: Routledge.

Angelaki, V. (2013). "Whose Voice? Tim Crouch's The Author and Active Listening on the Contemporary Stage". Silles Critiques, 16(13), s.1-16.

“An Article by Tim Crouch”. http://www.timcrouchtheatre.co.uk/ shows/the-author/the-author. (16.03.2018).

Barthes, R. (1974). S/Z. New York: Hill \& Wang.

--- (1977). Image Music Text. Fontana Press: London.

Biçer, A.G. (2016). “Tim Crouch’tan Çağdaş Dünyanın Suç Ortaklığına Davet”. Deniz Bozer (Ed.), Postdramatik Tiyatro ve İngiliz Tiyatrosu (s.144-168) Mitos Boyut: İstanbul.

Bottoms, S. (2011). “Introduction.” Tim Crouch, Tim Crouch: Plays One. Londra: Oberon, içinde s.11-20.

Cavendish, D. (2009). "The Author at the Royal Court Theatre Upstairs, review.”, The Telegraph. https://www.telegraph. co.uk/culture/theatre/theatre-reviews/6250036/TheAuthor-at-the-Royal-Court-Theatre-Upstairs-review.html. (16.03.2018).

Crouch, T. (2011a). Plays One. Oberon Books: London.

-- (2011b). "The Author: Response and Responsibility." Contemporary Theatre Review 21(4) s.416-422.

“England by Crouch". http://www.timcrouchtheatre.co.uk/shows/ england. (16.03.2018).

Fried, M. (1998). Art and Objecthood. Chicago: University of Chicago Press.

Gardner, L. (2009). "The Author". The Guardian.https://www. theguardian.com/stage/2009/sep/30/the-author-review. (06.03.2018).

Hale, D. J. (2006). The Novel: An Anthology of Criticism and Theory 1900-2000. Oxford: Blackwell.
İlter, S. (2011). “ 'A Process of My Transformation': Tim Crouch on My Arm." Contemporary Theatre Review 21(4) s.394-404.

Lane, D. (2010). Contemporary British Drama. Edinburgh: Edinburgh University Press.

Lehmann, H. T. (2006). Postdramatic Theatre. Londra: Routledge.

Mcmillan, J. (2010). "The Author." The Scotsmen. http:// edinburghfestivals.com/viewreview.aspx?id:1424. (09.03.2018).

Radosavljevic, D. (2013). Theatre Making: Interplay Between Text and Performance in the 21st Century. Londra: Palgrave Macmillan.

Rebellato, D. (2013). Modern British Playwriting 2000-2009. Londra: Bloomsbury Methuen Drama, s.125-144.

Sierz, A. (2009). "The Author, Royal Court". http://www.sierz. co.uk/reviews/author-royal-court/. (12.02.2018).

Verini, B. (2011). "Review: The Author. Variety. http://variety. com/2011/legit/reviews/the-author-1117944671/ (09.03.2018).

White, G. (2013). Audience Participation in Theatre: Aesthetics of the Invitation. New York: Palgrave Macmillan.

Willet, J. (2001). Brecht on Theatre: The Development of an Aesthetic. (Çev: John Willet), Londra: Methuen.

Woddis, C. (2009). "The Author". Reviews Gate. http://www. reviewsgate.com/index.php? name $=$ News $\&$ file $=$ article $\& s$ $\mathrm{id}=4747$. (16.03.2018). 